\title{
Introduction: Household and family in past time further explored
}

\author{
K. SCHÜRER*
}

The articles in this special issue of Continuity and Change arose from a workshop held in Palma de Mallorca, Spain, between 9 and 11 September 1999, hosted by the Universitat de les Illes Balears. The workshop was called to celebrate the thirtieth anniversary of another conference, that held in Cambridge at the Faculty of History and at Trinity College in September 1969. It was this conference in 1969 that resulted in the publication of Household and family in past time: comparative studies in the size and structure of the domestic group over the last three centuries in England, France, Serbia, Japan and colonial North America, with further material from Western Europe, which itself has just celebrated its thirtieth anniversary. ${ }^{1}$ Household and family in past time (hereafter abbreviated to HFPT), in part largely due to the "analytic introduction on the history of the family' contributed by Peter Laslett, subsequently became a seminal work in the field. It not only mapped out the methodological groundwork for the quantitative study of the historical co-resident domestic group, but perhaps unwittingly helped define a research agenda into comparative familial and social structural history that was followed for many years by Laslett, his colleagues at the Cambridge Group for the History of Population and Social Structure, and researchers from around the world. It became in a sense a manifesto, and one with which Peter Laslett personally was inexorably linked. Thus, with the sad death of Peter on 8 November 2001, this special issue of Continuity and Change took on a new double purpose: not only to mark the path-breaking 1969 conference and the subsequent publication of $H F P T$, but also to pay tribute to the remarkable life and work of Peter Laslett.

\footnotetext{
* Department of History, University of Essex.
} 
Thomas Peter Ruffell Laslett was born in Watford on 18 December 1915, the son of a Baptist minister. Following education at Watford Grammar School, he read history at St John's College, Cambridge, obtaining a double first. Years later he recounted a story of how he came to be awarded his degree. Following his finals he was summoned by Trevelyan, then Head of the Cambridge History Faculty, to the Master's Lodge of Trinity College. Trevelyan explained to the young Laslett that they were having difficulty in grading Peter's examination papers due to the fact that his handwriting was indecipherable - a feature that remained with Peter all his life. Peter was therefore asked to read his exam scripts out aloud. Halfway through the first paper Trevelyan interrupted. 'I've heard enough', he announced; 'First!' and Peter was dismissed. The story is typical of the way in which Peter made light of his achievements.

During the war Peter was recruited to the navy, serving initially on the dangerous protection of the Arctic route to Murmansk. Subsequently he was posted at Bletchley Park where he worked in naval intelligence on Japanese code-breaking projects. Following the war, Peter was employed at the $\mathrm{BBC}$ as a producer for the Third Programme, later to become Radio Three. It was during his time at the BBC that he developed his passionate belief and conviction that university-based research should be made available to the public in a clear and digestible form. He returned to Cambridge in 1948 to take up a fellowship at his old college, St John's. This was followed by a University Lectureship in 1953, which also saw him move to Trinity College, the 'high and mighty' as Peter would himself refer to it, where he remained as a fellow up until the time of his death.

An achievement of which Peter was particularly proud was his leading role, with his long-term friend and colleague, Michael Young, in the foundation of the Open University during the 1960s. Teaching degrees via radio and television broke the 'monopolies of universities', as Peter put it, and opened up higher education to those who for a variety of reasons were unable to partake in traditional university training. Likewise, during the 1980s Peter worked with both the late Lord Young and Eric Midwinter to found the University of the Third Age, a voluntary self-financed organization in which those aged 50 and over teach others of the same generation. Both the Open University and University of the Third Age projects illustrate Peter's passion for non-exclusive education. Peter was an energetic, enthusiastic teacher and a dedicated supervisor of research students. Above all he was an excellent communicator, in all forms and at all levels. Whether writing, addressing public audiences, teaching or just holding court as a conversationalist, Peter always conveyed original 
thought in a compelling yet provocative manner. He will be remembered as a formidable mentor by many.

From 1966 until his so-called 'retirement' in 1983, Peter was Reader in Politics and the History of Social Structure at the University of Cambridge. He was elected a Fellow of the British Academy in 1979, but for many it still remains a shocking omission that he was never appointed to a professorial chair by his alma mater. He was awarded a CBE in 1997. As was made clear at the memorial service held in Peter's honour at Trinity College in March 2002, Peter was very much a 'man for all seasons'. Addresses at that service reminded those present of Peter's role as a patron of the arts, both as a frequent purchaser of works of art and as commissioner of the architecture and 'design concept' of the house and home in which he lived for many years with his family in Clarkson Road, Cambridge. Equally, it revealed his passion for horticulture, in particular his love of English flowers and his devotion to the garden in Clarkson Road. But he was also a man of contradiction. He showed a healthy disregard for authority and tradition, yet at the same time took great pride and pleasure in entertaining numerous visitors at Trinity College, acting as a wonderful personal guide to the various College buildings, especially its Chapel. A Baptist minister's son sceptical of the Anglican Church, he adored church architecture, regarding the medieval churches of England as some of the country's finest architectural gems.

Many will know, especially readers of this journal, that the first stage of Peter's academic career was not with historical social structure, as he came to call it, but rather with the history of seventeenth-century political philosophy and political thought, in particular critically examining the underlying source materials. He edited Robert Filmer's Patriarcha in 1949 and John Locke's Two treatises of government in 1960, having previously rediscovered the library of Locke. ${ }^{2}$ However, many may not know what led to the transformation in his research agenda. He was clearly already thinking that what matters more in understanding society was a knowledge of social structures as a whole rather than individual thinkers, when in 1959 he was on sabbatical in the United States. Peter's particular 'road to Damascus' was the Library of Congress, Washington. He had noted a catalogue entry to the late-seventeenth-century Rector's Book for Clayworth, ${ }^{3}$ a village in Nottinghamshire, some months earlier whilst at the Huntington Library in California, but did not have the opportunity to inspect the volume until he was in Washington. The book contains two census-type listings of the 400 or so inhabitants of the village, for 1676 and 1688, compiled by the parish priest, William Sampson. Sampson was no ordinary rector, having previously been President of Pembroke College, Cambridge, where he was in charge of the college accounts, and in 1693 
was offered the Mastership of the College, which he declined, but quite why he should have decided to list each household in his parish and its occupants is unknown. The first list resulted from a collection being taken in the parish for the relief of fire victims in Northampton, but this would not have necessitated the listing of the inhabitants of the parish in itself. The reason for the second list is even more of a mystery. Whatever the reasons for their compilation, the impact of these two short listings on Laslett's thinking and subsequent writing was phenomenal. As he scanned the pages he could see no evidence for the sorts of patriarchal families that he expected to be present in seventeenth-century England, based on his knowledge of Filmer and the general perceived wisdom at the time. ${ }^{4}$ In his own words it was an 'intellectual shock' that he could see no sign whatever of the extended co-resident domestic group. Rather than being large and extended the households of Clayworth were small and simple. The mould had been cast. Peter immediately felt the need to search out similar sources in order to discover if the picture sketched by the Clayworth documents were representative or atypical.

The first presentation of this 'new' history of the co-resident group in early modern England took place at the Anglo-American Historical Conference, held in London, in 1961. Peter has been asked to talk on Locke ( $T$ wo treatises had been published the previous year) but chose instead to give a paper entitled 'Clayworth and Cogenhoe'. ${ }^{5}$ The discovery of the Clayworth listings and that for Cogenhoe also meant that the publication of The world we have lost ${ }^{6}$ the volume for which Peter is probably most readily remembered, had to be delayed in order to allow for re-writing and updating to take account of the new research findings. The book's roots lay in Peter's University lectures at Cambridge in the late 1950s. He was engaged to deliver lectures on the history of political history but decided in addition to teach on the history of social structure, including lectures on class and community composition, and the organization of work. Initial drafts of the future book where delivered in the form of broadcasts on the BBC's Third Programme, under the title 'The world we have lost', and subsequently published in The Listener magazine between 1960 and 1962. Following the addition of a chapter on historical demography (chapter 4) and a thorough revision of the sections on community structures (especially chapter 3 ), the book was eventually published in 1965.

It was while Peter was working on the new listings evidence and revising the text of The world we have lost that he met again with Tony Wrigley. The two rapidly discovered a common mutual interest in historical demography and the pioneering work of French demographers in this area, and as a result decided to form a joint research enterprise. At the time 
Wrigley was lecturing in the Geography Department at Cambridge, but he had first met Peter whilst studying as an undergraduate at Peterhouse, Cambridge. Modest research assistance for their joint projects was made possible by a number of small awards, initially from the History Faculty at Cambridge and Trinity College. A significant turning point came in April 1964 when Peter and Tony were awarded $£ 8,000$ over two years from the Calouste Gulbenkian Foundation. ${ }^{7}$ It was this success that led directly to the formation of what was to become the internationally famous Cambridge Group for the History of Population and Social Structure (although Peter referred to it initially in his diaries as just the 'Social Structure Group' and even toyed with calling it the Gregory King Group, after the seventeenth-century political arithmetician who calculated the population of England). The launch meeting of the Cambridge Group took place over the weekend of 10-12 July 1964. On the Saturday Alan Armstrong, Kenneth Connell, David Eversley, David Glass, Louis Henry, Tom Hollingsworth, and William Hoskins (together with Ralph Leigh to translate for Henry) met with Peter and Tony at rooms in Peterhouse to discuss the future plans and research agenda of the newly formed Group. In his diary Peter noted that it was an 'Interesting and exhausting morning: discussion of possibilities, progress and prospects' ${ }^{8}$ The day finished with those present all going to see the comic musical Knock on Wood, starring Danny Kaye, at the cinema.

The research work plan of the Group and associated methodology were unveiled in 1966 with the publication of An introduction to English historical demography. ${ }^{9}$ A critical plank in the Group's research undertakings was the recruitment of a national network of voluntary helpers. It was impossible within the limited resources of the Group to collect and transcribe all of the documentary evidence they intended for their nationally orientated investigations, if only because, at the time, parish registers were often still kept in the parish chests of the churches that had generated them. Radio broadcasts and other calls for help met with a tremendous response, and from this time the Group started in earnest to compile monthly and annual totals of baptisms, marriages and burials from parish registers, analyses of listings of inhabitants (the research files of which came to be known within the Group as the 'Red Books' as they were keep in red-covered ring-binders) and to continue the work of family reconstitution already started by Tony (on Colyton) and Peter (on Clayworth). The injection of man-power resulting from the call for volunteers not only proved important for the development of the Group's research, it also came to be the envy of those overseas - Louis Henry famously referred to it as 'le secret weapon Anglais'. ${ }^{10}$ The recruitment of volunteer labour also led to the creation of a new journal, Local Population Studies. 
Formed in 1967, originally as a newsletter to keep the volunteers informed of new findings and developments, it is still going strong.

The next milestone in the Cambridge Group's early history came in 1968. The initial grant from the Gulbenkian Foundation had been renewed for a second period allowing the appointment of Roger Schofield as Assistant Director of Research, but it was clear that other sources of funding to support the research effort would need to be found. An application to the newly founded Social Science Research Council proved to be the answer. This award gave the Group a greater level of security and permanency than it had previously enjoyed. It also enabled the Group to hire a new full-time research assistant to complete the reconstitution of Colyton to 1841 and link it to the census, and a systems analyst and a statistician to assist with the demographic studies. The research assistant was Richard Wall and he was soon asked by Peter Laslett to investigate whether Filmer's view of English families as patriarchal and households as large and complex was shared by his contemporaries and later commentators. Peter also summarized the results from the Group's analyses of listings for 'one hundred English parishes', taken to be representative of the country as a whole for the pre-industrial period. In order to discuss these findings and to place them in a wider geographical setting and comparative framework, the decision was taken to hold a meeting in Cambridge, inviting others known to be working on related issues concerning the history of the family and domestic group. The date for the conference was fixed for September 1969, and the draft paper summarizing the Group's work on English pre-industrial household structures was circulated to the participants. ${ }^{11}$ The paper made a clear and unequivocal announcement that the English evidence showed a consistent pattern of nuclear household formation, both spatially and temporally. The dominance of the nuclear family was further voiced by Laslett at the conference and later set out in his introduction to HFPT in the form of a null hypothesis - 'that the present state of evidence forces us to assume that its [the family's] organization was always and invariably nuclear unless the contrary can be proven'. ${ }^{12}$ The null hypothesis was to become one of the most commented-on features of HFPT, and one that Peter was later to regret ${ }^{13}$ as it was often subsequently misinterpreted and taken to mean that the nuclear family was the only form of residential unit across all societies. Despite this, or maybe even in part because of it, HFPT became a landmark publication for the study of historical social structures. The essays in this special issue are offered as a tribute to that volume, the Cambridge conference that gave birth to it, and to Peter Laslett, to whom subsequent scholars of the history of the family owe such a huge debt. 
A significant advance for the study of households and families since the publication of HFPT has been the development of large databases of census materials. This is nowhere more the case than in the United States, where national samples of the decennial census have been created for almost the entire period from 1850 to $1990 .{ }^{14}$ Marshalling this voluminous body of evidence, the article by Ruggles in this issue of Continuity and Change addresses many of the central themes of HFPT through an examination of the living arrangements of the elderly. In the USA this subset of the population, one in which Laslett was particularly interested in his later studies ${ }^{15}$ underwent a remarkable transition in terms of coresidence, from residing as part of multi-generational households in the mid-nineteenth century to living separately in the late twentieth century. Early critics of HFPT, especially Berkner, argued that, while nuclear families may have been in the numeric majority in given populations at a single point in time (as measured by a census), this does not necessarily preclude large numbers of individuals having lived as part of a multigenerational household at certain times over their life, or preclude multigenerational living being the desired form of residential organization. ${ }^{16}$ Emphasizing the development cycle, Berkner and others pointed to the fact that the formation of certain forms of multi-generational households, for instance stem families, may have been constrained by demographic circumstances in the past. ${ }^{17}$ Ruggles takes up this theme and argues that for most of the nineteenth century, due to a combination of high mortality, high fertility and long generational spans, the chances of offspring living with elderly parents were highly constrained, while in the late twentieth century they were less so. In the nineteenth century the majority of elderly persons who could live with their children did so, though in the late twentieth century the majority who could do so, did not. Ruggles also challenges another thesis proposed by Laslett in the years following the publication of $H F P T$, that where elderly persons did live with younger generations, this resulted out of necessity, due to widowhood, infirmity or poverty of the older generation. Examining the age pattern of coresidence and headship patterns as recorded in the censuses, Ruggles suggests that intergenerational dependency in the nineteenth century was in fact the other way around. While some elderly persons did move into the households of their children in later life, for the majority multigenerational living was the result of children not having moved out of the parental home. The process was one of economic rationality, with property ownership being a dominant factor. This pattern gradually broke down during the course of the twentieth century as the economic incentives for 
co-residence diminished. Furthermore, a detailed examination of the 1880 US census suggests that sickness and infirmity were not major causes of intergenerational living. For the period 1880 to 1920, multigenerational families were more likely to be associated with wealthier households, while in the second half of the twentieth century the reverse was true.

In contrast to the article by Ruggles, that by McCaa examines a population in which severe demographic conditions created no constraints on the formation of complex, multigenerational households. In his study of the Nahua (Aztec) Indians of Mexico in the 1540s, McCaa illustrates that despite horrendously high levels of mortality - he estimates that 15 per cent of children aged between five and nine had lost their fathers and that life expectancy at birth was around 20 or less - the demographic regime posed no obstacle to household complexity. Following strict rules of patriarchy (Filmer, it seems, should perhaps have lived in pre-Hispanic Mexico rather than seventeenth-century England) and a pattern of nearuniversal marriage, with girls marrying at pre-puberty ages and a marked age difference between partners at marriage, large compound bilateral co-resident groups were formed, with both uxorilocal and virilocal components. It would be difficult to find a society in which the null hypothesis posited by Laslett in HFPT could be more forcefully rejected. The residential groupings formed by the Nahua, suggests McCaa, were neither joint nor stem in the convention sense. They were not joint as they failed to conform to gendering rules, nor were they stem since, despite the prevailing patriarchy, lineage was not an important concept. Instead, they were compound groups, emphasizing the integration and connectivity between individual conjugal units rather than their separation. Togetherness through the performance of joint functions and activities was the underlying concept defining the Nahua household. In this they could be seen as economic units of interdependency as much as residential units. Due to the age structure of first marriage, husbands would usually move into the household of their wife, with headship subsequently often passing to the son-in-law. Thus sons were frequently disadvantaged by the demographic lottery. Widows were equally disadvantaged, with remarriage being rare for women, yet common for men. In the spirit of HFPT McCaa also compares the structure of the Nahua households of the 1540s with those in the region of rural Morelos as recorded in the 1990 census. He concludes that virtually no trace of the compound residential groups of the past can be found in modern Mexico. Instead the nuclear family is dominant. Still questions remain - why, how and when did this remarkable turnaround take place?

Although the studies presented in HFPT covered a wide-ranging geographical perspective, the volume did not explicitly propose a regional 
model of household formation in the past. This was to come later, most notably in Family forms in historic Europe, a publication that has been seen by many as a companion volume to $H F P T .{ }^{18}$ In his contribution to Family forms, Peter Laslett proposed a four-fold classification for the domestic group in traditional Europe. ${ }^{19}$ Following on and expanding upon the lead already taken by Hajnal, ${ }^{20}$ Peter proposed and listed a number of characteristics that the domestic group could be expected to display in four broadly defined geographical areas of Europe. (Interestingly, it was also in this chapter that Peter first mentioned that the 'Cambridge Group hopes to found the Journal of Historical Sociology to encourage research and publication' on 'countries where the familial system is so far illknown or entirely unknown, like Spain, Greece, and the countries of the south coast of the Mediterranean in North Africa'. ${ }^{21}$ It was from this proposal that the current journal Continuity and Change was formed.) Like the famous null hypothesis of HFPT this broad-brush categorization of the regions of Europe acted as a catalyst for subsequent researchers to call into question the applicability of such a general regional classification of historical household structures.

Following in this tradition, the contributions to this volume of both Moring and Viazzo examine the extent to which, respectively, the Nordic countries and the Mediterranean can be viewed as homogeneous regions of Europe in terms of the processes which shaped and defined household formation in the past. In her study of the available evidence for the five Nordic countries (Denmark, Finland, Iceland, Norway and Sweden), an area often depicted as stereotypical of the north-western European region, with simple households, late marriage and life-cycle service, Moring presents a general picture of heterogeneity rather than homogeneity. In particular she emphasizes the importance of ecology. In the Nordic countries geography matters, especially in terms of access to land and the quality of the land available. Household structures vary greatly between landholders and the landless, with the former having larger, often extended households characterized by earlier marriage and higher fertility, and the latter usually being smaller and simpler in composition. In short, underlying economic structures and opportunities shaped by environmental considerations combined to influence the nature of household types. This is illustrated in her study of coastal communities across the Nordic region which shows that household structures and organization were adapted to suit the prevailing economic activities. Moring's article also suggests that intervention from both the State and the Church could potentially impact on the formation of the domestic co-resident group, a factor often overlooked in other studies. In the case of the Nordic countries the former periodically intervened to regulate the number of servants households 
could or could not keep, while the Church laid down rules on the timing of marriage. From Moring's analysis of household forms in the Nordic countries it can be concluded that sweeping generalizations about prevailing household and demographic systems are both difficult and dangerous. If this is true of this particular corner of north-western Europe, can the same be said to be true of other regions? The study clearly points to the need for further micro-level studies of household structures linked to the economic opportunities which underpin them in order to understand more fully how the geographic mosaic of household systems fits together.

It was recognized in HFPT that the households of southern France and Italy may well be an exception to the prevalence of nuclear family types. However it was not until the appearance of Family forms that Laslett formally suggested the Mediterranean region as a type of family organization. The region, he suggested, could be categorized and was characterized by a number of prevailing features: a lack of neolocality (the formation of a new household on marriage) and a tendency toward complex households; early marriage for women and late marriage for men; very low proportions not marrying; a low incidence of remarriage for widows; and general lack of life-cycle servants. Unsurprisingly, Laslett's bold assertion generated a stream of research aimed at denouncing the use of 'Mediterranean' as a label for a common set of household structures and norms. In his article Viazzo provides a comprehensive review of what might be called the 'Mediterranean debate'. He demonstrates that work on Italian family structures, as well as those of other southern European countries, has destroyed the notion of any broad regional uniformity. Moreover it has shown that the prevailing assumptions relating to the interdependency between household formation and demographic processes are in some cases reversed. There are areas where early marriage is associated with simple family structures, and other areas where late marriage goes hand in hand with complex family groups; servants are found in areas typified by joint families (complex households containing two or more married couples from the same generation) and there are other areas dominated by nuclear families but with a distinct absence of life-cycle service. It would seem that the main actors involved failed to read the script prepared for them by Laslett and Hajnal. As with Moring's study of Nordic Europe, the structure of the co-resident group needs to be interpreted in terms of prevailing localized cultural, demographic, ecological and economic factors. However, despite this sea of variability, taking a lead from the work of Reher, ${ }^{22}$ Viazzo points to some factors that may differentiate, admittedly at a broad level, the familial structures of the Mediterranean countries from southern Europe from those of their neighbours to the north. He suggests a link between the occurrence of 
joint families and the 'perilous' existence or vulnerability of some of their members, especially incoming wives and the youngest members of the household. In this regard Viazzo interestingly points to the correspondence within Tuscany - the classic area of Italian sharecropping - of high proportions of joint family households and high levels of infant abandonment. Viazzo further suggests that perhaps a defining issue for the Mediterranean 'region' may not be the co-residence of family members per se but rather the co-existence of families, in other words, the roles, functions and expectations of kin both within and without the household.

In his introduction to HFPT Laslett was at pains to point out that the volume considered only the co-resident domestic group in the past, and was 'not concerned with the family as a network of kinship'. ${ }^{23}$ This deliberate omission from $H F P T$ was dictated largely by the simple lack of research on historical patterns of kinship at the time of the Cambridge conference in 1969. In their article here, Plakans and Wetherell provide an assessment of the work on kinship in the thirty-year period since the publication of HFPT. Following a compelling and engaging synthesis of the secondary literature, in the spirit of HFPT, the authors suggest a null hypothesis of their own. Their contention is that co-resident domestic groups of the past were in the main 'immune from strong influences from kin' outside of them. This proposition, they claim, 'has not been disproved by any findings now available'. Yet, they add, it is equally impossible to make a 'strong assertion that dyadic kin ties that crossed domestic group boundaries were unimportant'. The jury, it seems, is still out on the issue of kinship. In order to stimulate further research into kinship systems in the past and their interplay with domestic groups and changing residential arrangements, Plakans and Wetherell provide a guiding set of five major propositions and related corollaries which will surely serve as a research agenda for future studies.

When the idea of a celebratory meeting for the 1969 Cambridge conference was initially raised with Peter Laslett, after much discussion on the subject he somewhat reluctantly agreed to the proposal on one condition - that the meeting not be held in Cambridge! The organization of the resulting Palma meeting was assisted by generous financial support from both Trinity College, Cambridge and the Universitat de les Illes Balears. A tremendous personal debt is also owed to Isabel Moll Blanes of the Department Història, Universitat de les Illes Balears. Not only did she act as a tireless hostess during the three days of the meeting, but she also provided invaluable help and support to the author of this introduction in planning the programme for the meeting, as well as making all the local arrangements. Without her enthusiasm the meeting would not have been possible. Belinda Waterman also provided valuable administrative 
assistance in the organization of the Palma meeting. Out of necessity this volume contains only a subset of the papers presented at the Palma meeting. Others have been, or are in the process of being, published elsewhere. However, it is appropriate to note that the papers revised for this special issue all undoubtedly benefited from the discussions which took place in Palma. In addition to those contributing to this special issue the meeting included Michael Anderson, Anna Cabré, Enriqueta Camps, Marcus Cerman, Francisco Chacon, Antoinette Fauve-Chamoux, Leonore Davidoff, Jack Goody, Maria Antonia Gomila, John Hajnal, Tamara Hareven, Ralph Houlbrooke, Peter Laslett, James Lee, Isabel Moll, Michael Mitterauer, Jan Oldervoll, David Reher, Robert Rowland, David Sabean, Osamu Saito, Roger Schofield, Martine Segalan, Kirsi Sirén, Richard Smith, Solvi Sogner, Michel Verdon, Richard Wall and Zhongwei Zhao. Thanks are extended to all. The final acknowledgement must go to Richard Wall, not only as the co-editor of HFPT, but also for providing valuable comments on the articles which follow.

\section{ENDNOTES}

1 P. Laslett ed., with the assistance of R. Wall, Household and family in past time: comparative studies in the size and structure of the domestic group over the last three centuries in England, France, Serbia, Japan and colonial North America, with further material from Western Europe (Cambridge, 1972).

2 See P. Laslett, Patriarcha and other political works of Sir Robert Filmer (Oxford, 1949); P. Laslett ed., John Locke: two treatises of government (Cambridge, 1960). Locke's personal library was discovered at the home of the Earl of Lovelace, Ben Damph Forest. See J. Harrison and P. Laslett, The library of John Locke (Oxford, 1965).

3 H. Gill and E. L. Guilford eds., The rector's book, Clayworth, Notts. (Nottingham, 1910).

4 See, for example, P. Laslett, 'The gentry of Kent in 1640', Cambridge Historical Journal 9 (2) (1948), 148-64.

5 The lecture was subsequently published as P. Laslett and J. Harrison, 'Clayworth and Cogenhoe', in H. E. Bell and R. L. Ollard eds., Historical essays presented to David Ogg (London, 1963), 157-68 and in revised form as chapter 2 of P. Laslett, Family life and illicit love in earlier generations (Cambridge, 1977).

6 P. Laslett, The world we have lost (London, 1965).

7 In recognition of this financial support the HFPT volume was dedicated to James Thornton, then Director of the London Branch of the Gulbenkian Foundation.

8 Personal communication with Peter Laslett.

9 E. A. Wrigley ed., An introduction to English historical demography: from the sixteenth to the nineteenth century (London, 1966). The book is referenced on the title page as 'Cambridge Group for the History of Population and Social Structure. Publication No. 1 '.

10 It is also worth noting that key publication arising from the aggregate analyses of parish registers, E. A. Wrigley and R. S. Schofield, The population history of England: a reconstruction (London, 1981) is dedicated 'To the local population historians of England'. 
11 A revised version of this paper was subsequently published as P. Laslett, 'Mean household size in England since the sixteenth century', in P. Laslett with R. Wall eds., Household and family in past time (Cambridge, 1972) 125-58. Versions and abstracts of the paper also appeared prior to the publication of HFPT as P. Laslett, 'Size and structure of the household in England over three centuries. Part I', Population Studies 23 (1969), 199-223, and P. Laslett, 'The decline of the size of the domestic group in England', Population Studies 24 (1970), 449-54. Interestingly, in the first of these Population Studies articles Laslett noted that a second complementary article would appear in the same journal describing and analysing 'variations in mean household size by region and by period' (p. 199). Part II never appeared.

12 P. Laslett, 'Preface' to HFPT, $\mathrm{x}$.

13 For his defence and retraction of the statement see P. Laslett, 'The character of familial history, its limitations and the conditions for its proper pursuit', Journal of Family History 12 (1-3) (1987), 263-84, especially pp. 278-9.

14 See http://www.ipums.org.

15 As illustrated, for example, by P. Laslett, A fresh map of life: the emergence of the Third Age (London, 1989).

16 L. K. Berkner, 'The stem family and the development cycle of the peasant household', American Historical Review 77 (2) (1972), 398-418; 'Rural family organisation in Europe: a problem in comparative history', Peasant Studies Newsletter 1 (4) (1972), 145-56; 'The use and misuse of census data for the historical analysis of family structure', Journal of Interdisciplinary History 5 (4) (1975), 721-38.

17 A point that Laslett argued against; see $\mathrm{P}$. Laslett, 'The stem-family hypothesis and its privileged position', in K. W. Wachter with E. A. Hammel and P. Laslett, Statistical studies of historical social structure (New York, 1978).

18 R. Wall with J. Robin and P. Laslett eds., Family forms in historic Europe (Cambridge, 1983).

19 P. Laslett, 'Family and household as work group and kin groups: areas of traditional Europe compared', in Wall et al., Family forms, 513-63.

20 J. Hajnal, 'European marriage patterns in perspective', in D. V. Glass and D. E. C. Eversley eds., Population in history: essays in historical demography (London, 1965), 101-43. See also J. Hajnal, 'Two kinds of pre-industrial household formation system', in Wall et al., Family forms, 65-104.

21 Footnote 18, p. 531.

22 D. S. Reher, 'Family ties in Western Europe: persistent contrasts', Population and Development Review 24 (1998), 203-34.

23 P. Laslett, 'Introduction', in HFPT, 1. 